\title{
The Influence of Promotion and Product Quality on Purchase Decisions Mediated by Consumer Satisfaction at PT. Maybank Indonesia Finance
}

\author{
Adwar Indra Laksana ${ }^{1}$, Hery Winoto $\mathrm{Tj}^{2}{ }^{2}$, Soegeng Wahyoedi ${ }^{3}$ \\ ${ }^{1}$ Masters Program in Management Faculty of Economics and Business Krida Wacana Christian University \\ ${ }^{2,3}$ Faculty of Economics and Business Krida Wacana Christian University
}

\begin{abstract}
The purpose of the study was to determine the effect of promotion and product quality on purchasing decisions mediated by consumer satisfaction at PT. Maybank Indonesia Finance. The population is 1,097 people. The sampling technique used non-probability sampling with a sample of 100 respondents. Then processed using PLS-SEM. Promotion results have a significant effect on purchasing decisions, and product quality does not have a significant effect on purchasing decisions, for promotions has a significant effect on satisfaction, and for product quality does not have a significant effect on consumer satisfaction, for consumer satisfaction has a significant effect on purchasing decisions, and promotions have an effect significant effect on purchasing decisions that mediate consumer satisfaction, product quality does not have a significant effect on purchasing decisions that mediate consumer satisfaction.
\end{abstract}

KEYWORDS: Consumer Satisfaction, Promotion, Product Quality, Purchase Decision.

\section{INTRODUCTION}

The purchase decision is very important to think about because it will most likely affect how the company, in turn, implements its marketing plan. The company's ability to influence consumer purchasing decisions is supported by efforts to increase contact with consumers. Therefore, there are several factors that influence consumer buying decisions for a product that can come from within the consumer or from outside the consumer. (Kusumastuti, 2011: 2). The economic downturn has direct implications for the decline in people's purchasing power for the financing sector, especially car financing or usually called car loans. Multifinance plays an important role in the national economy, such as being an alternative source of money and/or purchasing assets and goods to the public.

In this context, the perceived impact is finance companies, namely in terms of car loans. Decreased interest in purchasing power of car loans. The fact that in fact the distribution of motor vehicles (cars) from January to August 2020 was only 323,507 units, strengthens this argument, when compared to the same period the previous year which sold 664,134 units, this achievement decreased by 51.3 percent. As is known, 50\%-60\% of consumers in Indonesia (especially car buyers) rely on credit, as a result it has an impact on various sectors such as finance companies which have a heavy impact. As a result, during the pandemic, several financial institutions tightened credit distribution criteria, one of which required a large down payment (DP) of up to 50\% to avoid bad loans. (Kompas. How Much Drop in Car Sales This Year Was Due to the Pandemic. https://otomotif.kompas. com. Accessed on Thursday, April 15, 2021. At 21.00 WIB).

One of the leading financing companies in Indonesia, especially in terms of car loans, which has experienced the impact of the economic downturn is PT. Maybank Indonesia Finance or usually called Maybank Finance, which is facing macroeconomic challenges during 2020, PT. Maybank Indonesia Finance continued to function successfully, although profit before tax fell by $1.3 \%$ to Rp.470 billion in 2020 despite a decline in total financing of 8.7\%. PT. Maybank Indonesia Finance al so remains focused on ensuring relatively stable asset management with an NPL gross margin of $0.3 \%$ and $0.2 \%$ net margin as of December 2020 compared to the same period last year, $0.3 \%$ and net margin. $0.1 \%$. Further information can be found in Table 1 below: 


\section{International Journal of Current Science Research and Review}

ISSN: 2581-8341

Volume 05 Issue 02 February 2022

DOI: 10.47191/ijesrr/V5-i2-33, Impact Factor: 5.825

IJCSRR@ 2022

www.ijcsrr.org

Table 1. Total Credit PT. Mavbank Indonesia Finance Periode 2019-2020

\begin{tabular}{|l|r|r|r|}
\hline \multicolumn{1}{|c|}{ Performance } & \multicolumn{1}{c|}{$\mathbf{2 0 2 0}$} & \multicolumn{1}{c|}{$\mathbf{2 0 1 9}$} & \multicolumn{1}{c|}{ Growth } \\
\hline Sale & 5.716 & 9.900 & $-42.3 \%$ \\
\hline Total Financing & 6.631 & 7.262 & $-8,7 \%$ \\
\hline NPL $(\%)$ & $0,31 \%$ & $0,27 \%$ & $0,04 \%$ \\
\hline Profit before tax & 470 & 476 & $-1,3 \%$ \\
\hline
\end{tabular}

Source: Maybank Indonesia Annual Report, (2020).

Meanwhile, in detail it can be explained that there is a decrease in car financing which is a benchmark for purchasing decisions, this is reinforced by Kotler and Keller (2012:226), purchasing decisions are based on preferences for brands that are part of choice set. It means in the correlation here that on the basis of the products four-wheeled vehicle products sold are cumulative in one part, namely the total financing of four-wheeled vehicles, so that the total financing of four-wheeled vehicles can be used as a benchmark in the decision to buy back at PT. Maybank Indonesia Finance. Therefore, it was noted that there was a decrease in total financing for four-wheeled vehicles, both new cars and used cars at PT. Maybank Indonesia Finance, which was Rp. 5.50 trillion, down $42.73 \%$ from 2019 of Rp. 9.61 trillion. This was due to a decrease in new car and used car financing, by $43.43 \%$ and $6.04 \%$, respectively. Further information can be found in Table 2 below:

Table 2. Total Financing Four Wheels (New Cars and Used Card) PT. Maybank Indonesia Finance 2019-2020

\begin{tabular}{|c|c|c|c|c|}
\hline \multirow[t]{2}{*}{ Description } & \multirow[t]{2}{*}{2020} & \multirow[t]{2}{*}{2019} & \multicolumn{2}{|c|}{ Growth } \\
\hline & & & Amount & $\%$ \\
\hline New Cars & 5.334 & 9.429 & $(4.095)$ & $-43,43 \%$ \\
\hline Used Cars & 170 & 181 & (11) & $-6,04 \%$ \\
\hline Total & 5.504 & 9.610 & $(4.107)$ & $-42,73 \%$ \\
\hline
\end{tabular}

Source: Maybank Finance Annual Report, (2020).

Furthermore, due to the impact of the economic downturn, the marketing costs incurred by PT. Maybank Indonesia Finance in this case the Promotional costs incurred in 2019 to 2020 decreased by $-2,369$, this is used as a benchmark for the Promotion, because according to Tjiptono (2015:219), promotion costs are costs incurred for marketing efforts. This means that marketing activities are part of promotion and are within the scope of marketing expenses, so that marketing expenses can be used as a reference or benchmark in promotion. For more details related to Promotional data of PT. Maybank Indonesia Finance in 2019-2020 can be seen in Table 3, below:

Table 3. Marketing (Promotion) Expenses PT. Maybank Indonesia Finance 2019-2020

\begin{tabular}{|c|c|c|}
\hline Marketing & 2020 & 2019 \\
\hline Promotional Expenses & 10.225 & 11.040 \\
\hline Other Banquet Expense & 2.457 & 3.981 \\
\hline Advertising Expenses & 86 & 116 \\
\hline Total & 12.768 & 15.137 \\
\hline
\end{tabular}

Source: Maybank Finance Annual Report, (2020).

To measure how far the level of Product Quality is, in this case the benchmark can be seen in the Sales Product Type Segment, this is according to PT. Maybank Indonesia Finance, is in line with As-sauri's (2014:155) opinion that a product can be created by considering market segmentation. Thus, the common thread can be drawn that the quality of a product can be measured based on the segment of the type of product being sold. As a result, in the 2019-2020 fiscal year, PT. Maybank Indonesia Finance 


\section{International Journal of Current Science Research and Review}

ISSN: 2581-8341

Volume 05 Issue 02 February 2022

DOI: 10.47191/ijcsrr/V5-i2-33, Impact Factor: 5.825

IJCSRR@ 2022

www.ijcsrr.org

experienced a decline. The sales product segment in financing new cars and used cars within the scope of finance companies, companies and market share decreased, further information can be seen in Table 4 as follows:

Table 4. Segment Type of Sales PT. Maybank Indonesia Finance 2019-2020

\begin{tabular}{|l|l|r|r|}
\hline \multicolumn{2}{|c|}{ Description } & \multicolumn{1}{|c|}{$\mathbf{2 0 2 0}$} & \multicolumn{1}{c|}{$\mathbf{2 0 1 9}$} \\
\hline \multirow{3}{*}{ New Car Financing } & Financing Company & 112,225 & 135,976 \\
\cline { 2 - 4 } & Company & 5,334 & 9,429 \\
\cline { 2 - 4 } & Market Share (\%) & 4.75 & 6.93 \\
\hline \multirow{3}{*}{ Used Car Financing } & Financing Company & 53,389 & 58,456 \\
\cline { 2 - 4 } & Company & 170 & 181 \\
\cline { 2 - 4 } & Market Share (\%) & 0.30 & 0.31 \\
\hline
\end{tabular}

Source: Maybank Finance Annual Report, (2020).

In the direction of consumer satisfaction at PT. Maybank Indonesia Finance in 2019-2020, which was affected by the economic downturn, can be seen from the level of performance, this can be used as a one of the benchmarks because performance can show the final result of the entire system that works in a company, so this can be used as the final accumulation of consumer satisfaction, this is reinforced by consumer satisfaction according to Priansa (2017: 196), is a sensation someone's pleasure or disappointment that arises after comparing the expected product performance (result) with the expected performance (result). Therefore, the benchmark for consumer satisfaction is seen from the performance at PT. Maybank Indonesia Finance experienced a decline, wherein its total revenue decreased by $-1.88 \%$. This can be more clearly understood in Table 5, below:

Table 5. Performance of PT. Maybank Indonesia Finance 2019-2020

\begin{tabular}{|l|r|r|r|}
\hline \multirow{2}{*}{\multicolumn{1}{|c|}{ Description }} & \multicolumn{3}{c|}{ Total } \\
\cline { 2 - 4 } & \multicolumn{1}{c|}{$\mathbf{2 0 2 0}$} & \multicolumn{1}{c|}{$\mathbf{2 0 1 9}$} & \multicolumn{1}{c|}{$\%$} \\
\hline Consumer finance & 1.000 .324 & 1.012 .773 & $-1,23$ \\
\hline Lease Financing & 110.987 & 117.635 & $-5,65$ \\
\hline Jjarah Rental - Net & 2.754 & 2.847 & $-3,27$ \\
\hline Interest Income & 9.423 & 9.287 & 1,46 \\
\hline Other Income & 35.534 & 38.713 & $-8,21$ \\
\hline Total Income & $\mathbf{1 . 1 5 9 . 0 2 2}$ & $\mathbf{1 . 1 8 1 . 2 5 5}$ & $\mathbf{- 1 , 8 8}$ \\
\hline
\end{tabular}

Source: Maybank Finance Annual Report, (2020).

From all the data that has been explained above in various variables, then these data show that overall at PT. Maybank Indonesia Finance, both in terms of purchasing decision variables, promotions, and product quality and consumer satisfaction have decreased. Consequently, the authors support the claim using statistics comparing the target and actual performance of PT. Maybank Indonesia Finance in 2019-2020, where the achievement between income and expenses has not been realized properly, this can be seen in Table 6, below:

Table 6. Comparison of Target and Realization of PT. Maybank Indonesia Finance 2019-2020

\begin{tabular}{|l|r|r|r|}
\hline \multicolumn{1}{|c|}{ Description } & $\begin{array}{c}\text { Business Plan } \\
\text { Target 2020 }\end{array}$ & Realization 2020 & Achievement \\
\hline Income & 1.303 .922 & 1.159 .022 & $88,89$. \\
\hline Burden & 949.848 & 687.109 & $72,34$. \\
\hline
\end{tabular}

Source: Maybank Finance Annual Report, (2020). 


\title{
International Journal of Current Science Research and Review
}

ISSN: 2581-8341

\author{
Volume 05 Issue 02 February 2022
}

DOI: 10.47191/ijcsrr/V5-i2-33, Impact Factor: 5.825

In making a purchase decision made by consumers, of course, it is influenced by sales promotions and products offered so that later the consumer will make a purchase decision, of course this is, because in the hope that consumers will get consumer satisfaction, but this does not always go well. Because of course there are obstacles faced. Therefore, the issue that becomes the problem of the influence of promotions and products on purchasing decisions in strengthening and weakening consumer satisfaction, several issues can be drawn including the following:

1. The impact of the national economic downturn and not to mention the intense business competition, resulting in a decrease in product sellers, this is caused by several factors, one of which is not understanding effective promotion in the midst of this pandemic, so It is not necessary to understand about effective promotion methods as an effort to provide a reference for consumers to make their purchasing decisions.

2. On the other hand, when there is a decline in sellers, the factor is that the decline is caused because the products offered to consumers are not in accordance with the standards desired by consumers, so it is necessary to re-evaluate the product, taking into account the improvement in the quality of the products offered to consumers., and at the same time determine the criteria for what kind of product consumers want, so that later consumers will make purchasing decisions in the hope that consumers believe and are satisfied with the products offered, so that later on the basis of satisfaction from these consumers, then consumers will buy more of the products offered.

Based on the previous explanation, it can be concluded that the existence of consumer satisfaction as a result of consumer demand is one of the many factors that contribute to the formation of new companies in the same industry, giving rise to intense competition in the business world, especially with current conditions. Which is where the business world has experienced a decline in results, especially multi-finance companies. Therefore, the financing company namely PT. Maybank Indonesia Finance, which has a broad market share, must be able to dominate market share with new companies that have different marketing strategies. PT. Maybank Indonesia Finance must be observant in forming consumer interest in buying car loans on a product offered by offering attractive promotions, so that consumers will make a decision to purchase car loans in the hope that consumers will get purchase satisfaction. The author is interested in conducting research based on the background discussed above with the title "The Influence of Promotion and Product Quality on Purchase Decisions Mediated by Consumer Satisfation at PT. Maybank Indonesia Finance".

\section{FORMULATION OF THE PROBLEMS}

Based on the background context above, the following is an expression for the formulation of the problem, namely:

1. Is there any effect of promotion on purchasing decisions at PT. Maybank Indonesia Finance?

2. Is there any influence of product quality on purchasing decisions at PT. Maybank Indonesia Finance?

3. Is there any effect of promotion on consumer satisfaction at PT. Maybank Indonesia Finance?

4. Is there any influence of product quality on consumer satisfaction at PT. Maybank Indonesia?

5. Is there any influence of consumer satisfaction on purchasing decisions at PT. Maybank Indonesia Finance?

6. Is there any effect of promotion on purchasing decisions mediated by consumer satisfaction at PT. Maybank Indonesia Finance?

7. Is there any influence of product quality on purchasing decisions mediated by consumer satisfaction at PT. May-bank Indonesia Finance?

\section{LITERATURE REVIEW}

Promotion

According to Rangkuti in Hermawan, et al, (2021). Promotion is an effort or effort to advance or improve, for example to increase trade or advance the field of business. Promotion comes from the word promote in English which is meant to increase or increase. This interpretation when associated with the field of sales means as a tool to increase sales results. From some of the interpretations above, it can be concluded that promotion is a form of marketing activity that seeks to share product data and attempts to influence consumers with the aim of encouraging consumers to create sales. 


\title{
International Journal of Current Science Research and Review
}

ISSN: 2581-8341

\author{
Volume 05 Issue 02 February 2022
}

DOI: 10.47191/ijcsrr/V5-i2-33, Impact Factor: 5.825

Promotion functions as seeking and getting the attention of potential buyers, creating and growing interest in potential buyers, developing a sense of curiosity (desire) for potential buyers to have the object being offered. After someone is interested in a product, it makes sense to be able to have it. (Nasution, 2017).

According to Boone and Kurtz, in Sudaryono, (2016: 51), there are promotion objectives that can provide the achievement and success of the promotion, so that the promotion objectives are to provide information, to differentiate a product, to increase sales, stabilize sales or sales stabilization, highlight the value of the product.

Promotional activities are not carried out by introducing the product to consumers but must be pursued with efforts to influence it so that consumers are satisfied and subsequently buy the product. According to Swastha, (2011: 245-248), there are indicators in promotion which are grouped into several sections, namely, among others:

1. Advertising, a paid form of non-personal communication through various media by companies, non-profit organizations and individuals. Advertisements reach the general public (general public), not individuals but directly to audiences (not individuals) and can convey ideas convincingly and with dramatic effect (ad expression).

2. Promotion is a business activity that sells marketing products so that consumers can see them easily, even with certain locations and arrangements the product will attract the attention of consumers.

3. Publicity, is the amount of information about a person, thing or organization that is released by the media for free or without sponsor's supervision.

4. Personal selling or Personal selling, is a face-to-face interaction between people with the aim of creating, improving, controlling or maintaining mutually beneficial exchange relationships with other parties.

\section{Product Quality}

Understanding the product According to Tjiptono (2015: 231), is the subjective understanding of the producer about something that can be provided as an effort to achieve organizational goals by meeting the needs and desires of consumers, in accordance with the capacity and ability of the organization as well as purchasing power. Market. From the above understanding of product quality, it can be concluded that product quality is a constantly changing condition, including products, services, people and processes, and the environment, to meet or exceed consumer and business expectations.

According to Kotler and Keller (2016: 390), there are five product levels, namely:

1. Core benefits, are core benefits that are planned for solving problems that consumers seek or complain about when they buy or use products or services.

2. Basic Product, is a basic benefit that is developed from the core product or in other words something that is complementary and absolutely owned.

3. Expected Product, is a complete set of attributes and conditions of a product that is received by consumers when the product is purchased.

4. Additional Product, is an additional benefit that can add value to the product and differentiate it from competing products.

5. Potential Products, is how the future expectations of the product if there is a change in technological developments and consumer tastes.

According to Wijaya (2018:13), describing factors that can be categorized as having superior or high-quality products (Product Quality Factors), including good design. The design must be original and captivate the taste of consumers. For example, a refined design to get the impression of quality, superiority in competition, the product must be superior in both function and design when compared to other similar products, physical attractiveness. The product must appeal to the senses (appeal to touch or feel), must have a good brand, and must be beautiful, authentic. Derivative or imitation product indicates that the quality of the derivative is not as good as the original product or the main product.

Product quality indicators, according to Tjiptono (2012:121), can be identified as characteristics of product quality, as follows:

1. Performance, that is to say, the main performance characteristics of the obtained Core Products: speed, fuel consumption, number of passengers that can be carried, ease of operation and comfort, and so on.

2. Additional features, namely secondary characteristics or as a complement, for example interior and exterior completeness.

3. Reliability, meaning that it is less likely to be damaged or unusable, such as not breaking down, jamming, fussing, or breaking down. 


\section{International Journal of Current Science Research and Review}

ISSN: 2581-8341

Volume 05 Issue 02 February 2022

DOI: 10.47191/ijcsrr/V5-i2-33, Impact Factor: 5.825

IJCSRR@ 2022

www.ijcsrr.org

4. Conformance Specifications, the extent to which the design and performance meet predetermined criteria.

5. Durability, regarding how long the product can continue to be used, these parameters include the technical life and economic life of the vehicle.

6. Aesthetics, meaning how attractive the product is seen by consumers.

\section{Purchase Decisions}

According to Tjiptono, (2014:21). A purchase decision is a series of processes that lead to a purchase decision, starting with the consumer recognizing the problem, seeking information about a particular product or brand, and evaluating the product or brand for how well each alternative solves the problem. Based on the above opinion, it can be concluded that purchasing decisions are actions by customers to purchase a product or service through various alternative choices that already exist and then from these alternative choices can determine attitudes. which is taken next.

In making a decision, of course there is a process that is passed or there are stages, so according to Ko-tler and Keller (2016: 186), there are several stages of which it is clearer in the description as follows:

1. Problem Recognition Stage The buying process begins when the buyer becomes aware of a problem or need caused by an internal or external stimulus.

2. Information Search Stage, is a stage in the buyer's decision-making process where consumers are interested in seeking more information, where they simply increase their interest or actively seek information.

3. Alternative Evaluation Stage, is a buyer step where consumers use information to evaluate various alternative service providers they choose.

4. The Purchase Decision Stage is an individual activity that is directly related to the purchase decision on the product offered by the seller.

5. Post-Purchase Behavior Stage, occurs when consumers engage in post-purchase activities and use products or services that may be of interest to marketers.

According to Kotler and Armstrong, (2013: 214), as for the buying decision factors, namely Culture is a determinant, desire, action and is reflected in lifestyle, customs and traditions, and demand for various goods and services, then social factors also influence buyer behavior. Product selection is strongly influenced by small groups, family, friends, role and social status of consumers, and personal factors as much as influenced by individual characteristics such as age and life cycle stage, occupation, economic status, lifestyle, and consumer personality, and psychological factors are a series of psychological processes combined with certain consumer characteristics that form the decision-making process and purchase decisions.

According to Kotler and Keller (2016: 183), there are several indicators in purchasing decisions, including:

1. Product selection, consumers will decide which products to buy and consumers will buy products that have value.

2. Brand Selection, consumers must decide which brand to buy.

3. Purchase Channel Selection, consumers must decide which dealer to visit.

4. Determination of Purchase Time, consumer decisions in determining when a purchase will be made.

5. Number of Purchases, consumers can decide how many products to buy at one time.

6. Payment Methods, consumers can decide which payment method will be used to make consumer decisions about the use of a product or service.

\section{Consumer Satisfaction}

According to Sangadji and Sopiah (2013: 181), customer satisfaction is defined as a condition where consumer expectations for a product are in accordance with the reality received by consumers. Consumers will be disappointed if the product is much lower than expected. Conversely, if a product meets expectations, consumers will be satisfied. It can be concluded that customer satisfaction is an expression of the pleasure of feeling happy and a consumer's personal frustration or frustration that appears after the consumer compares the expectations and reality obtained for the results of a product.

Tjiptono, (2011: 310), measuring consumer satisfaction is very useful for a company in order to evaluate the company's current position compared to competitors and end users, and find which parts need improvement. According to Lupiyoadi (2013:158), business must consider five factors when determining customer satisfaction, including:

1. Product Quality, as a result of the evaluation, if the product used is of good quality, the customer will be satisfied. 


\section{International Journal of Current Science Research and Review}

ISSN: 2581-8341

\section{Volume 05 Issue 02 February 2022}

DOI: 10.47191/ijcsrr/V5-i2-33, Impact Factor: 5.825

2. Quality of Service, especially in the service industry, customers will feel satisfied if they get good service or the expected service.

3. Emotional, customers will be proud and have strong confidence when consumers use the product and other people will admire it, so consumers will feel comfortable with the product used.

4. Prices, the same quality but relatively cheap products, will give the same impression without changing the essence of the product.

5. Cost, customers do not need to incur costs, additional costs, or spend time to get products or services in general, enough with products or services that are economical in cost plus quality value, then consumers will be satisfied.

Furthermore, according to Setyo (2017), consumer satisfaction can be assessed or can be measured from what is expected by consumers. Therefore, there are indicators of customer satisfaction, namely:

1. Fulfillment of consumer expectations, consumers are satisfied with satisfying their needs and desires for a product or service.

2. Attitude or Desire to Use Products is an acquired tendency, meaning that attitudes related to purchasing behavior are formed as a result of direct experience with a product, verbal information received from other people, or as a result of the media. email, the internet, and various forms of direct marketing advertising.

3. Recommending to Other Parties, satisfied consumers will recommend the results of their experiences using or buying a product to others for what they have experienced.

4. Quality of Service, can be realized through the accuracy of delivery to balance consumer expectations with the satisfaction of consumer needs.

5. Loyal, consumers have various reasons why they may not be loyal to a particular product or service that may be profitable or meet their expectations.

6. Good reputation, for companies whose main products are services, reputation and commodity name existence determines the assumption that brand image, the best reputation among service products is very good, all get priority related to customer satisfaction.

7. Location, is a place where business actors carry out the sale and purchase of goods/services, some of which are given to consumers.

\section{Conceptual Framework}

The following below will explain the image which is a schematic of the framework that can be seen through Figure 2.5, as follows:

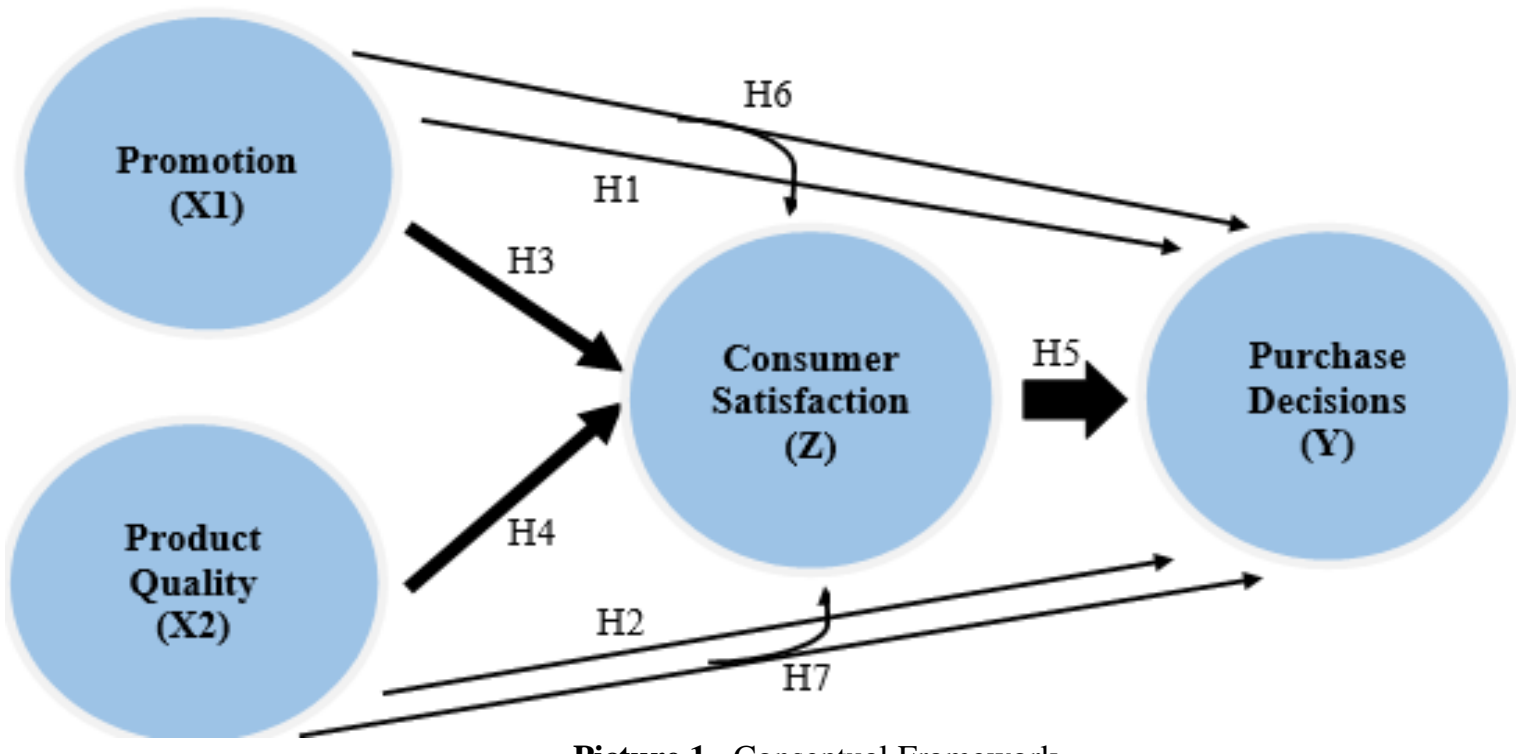

Picture 1. Conseptual Framework

Source: Data Processed by Author 


\section{International Journal of Current Science Research and Review}

ISSN: 2581-8341

Volume 05 Issue 02 February 2022

DOI: 10.47191/ijcsrr/V5-i2-33, Impact Factor: 5.825

\section{Hypothesis Development}

Based on the framework above, the researcher decides that there is a hypothesis in this study which is temporary in nature, temporary because it must be proven by relevant theories and facts, therefore the hypothesis in this study is as follows:

1. H1: There is an effect of Promotion on Purchase Decision.

2. H2: The influence of product quality on purchasing decisions.

3. H3: There is an effect of Promotion on Consumer Satisfaction.

4. H4: There is an effect of Product Quality on Consumer Satisfaction.

5. H5: The influence of consumer satisfaction on purchasing decisions.

6. H6: There is an effect of Promotion on Purchase Decisions Mediated with Consumer Satisfaction.

7. H7: There is an effect of Product Quality on Purchase Decisions Mediated with Consumer Satisfaction.

\section{RESEARCH METHODS}

To answer all the questions in this research, which have been formulated above, a research method is needed that acts as a knife for analyzing a problem. According to Sugiyono, (2017:3), the research method is a scientific analysis to obtain data for certain purposes and uses. In this study, the object of research is several variables including Promotion and Product Quality and Purchase Decisions, as well as Consumer Satisfaction, which is the subject of this research, namely the consumers of PT. Maybank Indonesia Finance, which carries out credit financing at PT. Maybank Indonesia Finance, and when the research was conducted in the period January 2021-March 2022, and the location of this research was PT. Maybank Indonesia Finance in several representative offices, among others, at PT. Maybank Indonesia Finance representative offices in Cikarang, Cilegon, Lombok, Jember, and Pal-angkaraya, as well as Thorns.

In this study the population is the consumers of PT. May-bank Indonesia Finance, which carries out credit financing at PT. Maybank Indonesia Finance, with a total population of 1,097 people with a population period taken in June 2021-July 2021. In determining which data will be studied, the sampling technique used is the non-probability sampling method, which according to Sugiyono (2013:120) used a sampling method that does not provide equal opportunities for each element or member of the population that can be selected as a sample and is obtained through intentional sampling in a way that is used in the form of purposive sampling. Based on the results of the calculation using the formula, the authors set a sample of 100 respondents. That way a sample of 100 respondents can already represent the existing population.

To find out the data collection techniques in the study, using a questionnaire, observation and literature study. Meanwhile, the data analysis used was descriptive analysis with the first stages, editing, scoring, tabulating, and descriptive analysis design were carried out by determining the number of criteria scores, comparing the total scores from the questionnaire results with the number of criteria scores, creating a continuum category area. , and determine the comparison of the continuum scores of each level with a view to getting the difference, as well as selecting the high continuum category that has been made from high, medium and low.

Then, after that, an analysis was carried out using Smart PLS-SEM (Partial Least Square-Structural Equation Modeling)based software, with data analysis steps to create a structural model (Inner Model) and measurements (Outer Model), then evaluate the Measurement Model (Outer Model) with analysis of convergent validity, discriminant validity, average variance extracted (AVE), and composite reliability, then the next step is to evaluate the Structural Model (Inner Model) with analysis using R-Analysis Square (R2), multicollinearity, F2 analysis on effect size, Q-Square Predictive Relevance analysis, and Goodness of Fit (GoF) analysis. Furthermore, hypothesis testing is carried out and finally the mediation effect analysis is carried out.

\section{ANALYSIS AND DISCUSSION}

\section{Characteristics of Respondents}

First, the characteristics of gender show that men are $73 \%$ and the rest are women with a value of $27 \%$. The two characteristics of respondents based on age showed 1 respondent at the age of 18-25 years, and aged 25-35 years as many as 59 respondents, while at the age of 35-45 years as many as 38 respondents, and aged over 50 years as many as 2 respondents. Third, based on the latest education, it is found that on average many respondents have the latest education, namely Bachelor, with 64 


\section{International Journal of Current Science Research and Review}

ISSN: 2581-8341

Volume 05 Issue 02 February 2022

DOI: 10.47191/ijcsrr/V5-i2-33, Impact Factor: 5.825

respondents. Fourth, based on occupation, it was found that most of the respondents' occupations were self-employed, namely as many as 51 respondents. The fifth is based on the city where the consumers live, namely Palngkaraya with 20 people, then 18 in Cilegon, 16 in the Cikarang area and 16 people in the Duri area, then 15 in Jember. and Lombok by 15 people. Sixth, the financing of products/services taken is that the highest amount is financing for four-wheeled vehicles, which is 95 people, or with a percentage of $95 \%$. The seven incomes per month are from respondents with a monthly income of Rp. 3,000,000-Rp. 4,000,000, as many as 1 respondent. Furthermore, respondents with a monthly income of Rp. 4,000,000-Rp. 5,000,000, as many as 9 respondents, as well as income per month of more than Rp. 5,000,000 as many as 90.

\section{Respondents Response}

The average value of the answers to 100 respondents in the promotion variable is 4.38 with this rating, then this shows that the respondents feel very satisfied with the promotions carried out by PT. Maybank Indonesia Finance, and the average value of the respondents' answers is 4.23 , with the value obtained in the product quality variable, it can be interpreted that several indicators in the product quality variable are very good or very satisfied. Then, in the response to the purchase decision variable, most of the respondents answered that the value was 4.30. This means that it can be said that the respondent's answer is very good or very satisfied, and on the variable consumer satisfaction the average response is 4.35 , so it can be interpreted that the respondent is very satisfied given by PT. Maybank Indonesia Finance.

\section{Convergent Validity}

The loading factor test results show that the results of the convergent validity value have met, because all loading factors are more than a value of 0.6, which means that all variables and indicators in this study are quite good or acceptable. More details can be seen in the table below:

Table 7. Convergent Validity (Outer Loading) Value

\begin{tabular}{|l|l|l|l|l|}
\hline & X1 & X2 & Y & Z \\
\hline X1_1 & 0.684 & & & \\
\hline X1_2 & 0.660 & & & \\
\hline X1_3 & 0.806 & & & \\
\hline X1_4 & 0.805 & & & \\
\hline X2_1 & & 0.692 & & \\
\hline X2_2 & & 0.751 & & \\
\hline X2_3 & & 0.808 & & \\
\hline X2_4 & & 0.727 & & \\
\hline X2_5 & & 0.788 & & \\
\hline X2_6 & & 0.697 & & \\
\hline Y1 & & & 0.681 & \\
\hline Y2 & & & 0.765 & \\
\hline Y3 & & & 0.816 & \\
\hline Y4 & & & 0.816 & \\
\hline Y5 & & & 0.793 & \\
\hline Y6 & & & 0.639 & \\
\hline Z1 & & & & 0.825 \\
\hline Z2 & & & & 0.699 \\
\hline Z3 & & & & 0.683 \\
\hline Z4 & & & & 0.726 \\
\hline Z5 & & & & 0.706 \\
\hline Z6 & & & & 0.761 \\
\hline Z7 & & & & 0.670 \\
\hline
\end{tabular}

Source: Results of Author Processed Data From Smart PLS-SEM, (2021). 


\section{International Journal of Current Science Research and Review}

ISSN: 2581-8341

Volume 05 Issue 02 February 2022

DOI: 10.47191/ijesrr/V5-i2-33, Impact Factor: 5.825

IJCSRR@ 2022

www.ijcsrr.org

\section{Discriminant Validity}

The results of discriminant validity based on cross loading show that all construct relationship values on the existing indicators are greater or higher than the other indicator blocks, so that all constructs show good discriminant validity. More details can be seen in the table below:

Table 8. Discriminant Validity Value (Cross Loading)

\begin{tabular}{|l|l|l|l|l|}
\hline & X1 & X2 & Y & Z \\
\hline X1_1 & $\mathbf{0 . 6 8 4}$ & 0.098 & 0.541 & 0.493 \\
\hline X1_2 & $\mathbf{0 . 6 6 0}$ & 0.087 & 0.577 & 0.462 \\
\hline X1_3 & $\mathbf{0 . 8 0 6}$ & 0.188 & 0.643 & 0.651 \\
\hline X1_4 & $\mathbf{0 . 8 0 5}$ & 0.297 & 0.669 & 0.571 \\
\hline X2_1 & 0.073 & $\mathbf{0 . 6 9 2}$ & 0.211 & 0.162 \\
\hline X2_2 & 0.247 & $\mathbf{0 . 7 5 1}$ & 0.257 & 0.273 \\
\hline X2_3 & 0.213 & $\mathbf{0 . 8 0 8}$ & 0.268 & 0.273 \\
\hline X2_4 & 0.052 & $\mathbf{0 . 7 2 7}$ & 0.159 & 0.168 \\
\hline X2_5 & 0.233 & $\mathbf{0 . 7 8 8}$ & 0.282 & 0.284 \\
\hline X2_6 & 0.144 & $\mathbf{0 . 6 9 7}$ & 0.196 & 0.149 \\
\hline Y1 & 0.584 & 0.245 & $\mathbf{0 . 6 8 1}$ & 0.548 \\
\hline Y2 & 0.634 & 0.192 & $\mathbf{0 . 7 6 5}$ & 0.545 \\
\hline Y3 & 0.684 & 0.168 & $\mathbf{0 . 8 1 6}$ & 0.722 \\
\hline Y4 & 0.590 & 0.322 & $\mathbf{0 . 8 1 6}$ & 0.645 \\
\hline Y5 & 0.679 & 0.238 & $\mathbf{0 . 7 9 3}$ & 0.606 \\
\hline Y6 & 0.534 & 0.279 & $\mathbf{0 . 6 3 9}$ & 0.603 \\
\hline Z1 & 0.597 & 0.324 & 0.699 & $\mathbf{0 . 8 2 5}$ \\
\hline Z2 & 0.645 & 0.253 & 0.682 & $\mathbf{0 . 6 9 9}$ \\
\hline Z3 & 0.456 & 0.250 & 0.496 & $\mathbf{0 . 6 8 3}$ \\
\hline Z4 & 0.442 & 0.147 & 0.604 & $\mathbf{0 . 7 2 6}$ \\
\hline Z5 & 0.554 & 0.220 & 0.539 & $\mathbf{0 . 7 0 6}$ \\
\hline Z6 & 0.570 & 0.113 & 0.580 & $\mathbf{0 . 7 6 1}$ \\
\hline Z7 & 0.444 & 0.191 & 0.486 & $\mathbf{0 . 6 7 0}$ \\
\hline Sor & \\
\hline
\end{tabular}

Source: Results of Author Processed Data From Smart PLS-SEM, (2021).

Average Variance Extracted AVE

That the average variance extracted (AVE) value on the promotion variable (X1) is 0.550 , while the quality variable (X2) is 0.555 , then the purchasing decision variable $(\mathrm{Y})$ is 0.570 , and the consumer satisfaction variable $(\mathrm{Z})$ is 0.527 . So it can be concluded that all variables in this study are above an average of 0.50 , meaning that each variable is feasible. More details can be seen in the table below:

Table 9. Average Variance Extracted (AVE) Value

\begin{tabular}{|l|l|}
\hline & Average Variance Extracted (AVE) Value \\
\hline Promotion (X1) & 0.550 \\
\hline Product Quality (X2) & 0.555 \\
\hline Purchase Decisions (Y) & 0.570 \\
\hline Consumer Satisfation (Z) & 0.527 \\
\hline
\end{tabular}

Source: Results of Author Processed Data From Smart PLS-SEM, (2021). 


\section{International Journal of Current Science Research and Review}

ISSN: 2581-8341

Volume 05 Issue 02 February 2022

DOI: 10.47191/ijesrr/V5-i2-33, Impact Factor: 5.825

\section{Composite Reliability}

Composite reliability value. The construct is declared reliable, if the composite reliability has a value $>0.7$, then the construct is declared reliable. The result is that each variable has a value of more than 0.70 , so it can be interpreted that the reliability of the variable is met. More details can be seen in the table below:

Table 10. Composite Reliability Value

\begin{tabular}{|l|l|}
\hline & Composite Reliability Value \\
\hline Promotion (X1) & 0.829 \\
\hline Product Quality (X2) & 0.882 \\
\hline Purchase Decisions (Y) & 0.887 \\
\hline Consumer Satisfation (Z) & 0.886 \\
\hline
\end{tabular}

Source: Results of Author Processed Data From Smart PLS-SEM, (2021).

\section{R-Square $\left(\mathbf{R}^{\mathbf{2}}\right)$}

That the R-square value in the purchasing decision variable (Y) shows a value of 0.74 , while the results of the consumer satisfaction variable $(\mathrm{Z})$ in the $\mathrm{R}$-square value show a result of 0.564 , so it can be concluded that the $\mathrm{R}$-square value in this study it is said to be good, because the results of the purchasing decision variable (Y) are above 0.67 , so it is said to be very good, while the consumer satisfaction variable $(\mathrm{Z})$ is above 0.33 , so it is said to be good. For more details, see the table below:

Table 11. R-Square $\left(\mathrm{R}^{2}\right)$ Value

\begin{tabular}{|l|c|}
\hline & \multicolumn{2}{|c|}{$\begin{array}{c}\text { R-Square }\left(\mathbf{R}^{\mathbf{2}}\right) \\
\text { Value }\end{array}$} \\
\hline $\begin{array}{l}\text { Purchase } \\
\text { Decisions (Y) }\end{array}$ \\
\hline $\begin{array}{l}\text { Consumer } \\
\text { Satisfation (Z) }\end{array}$ & 0.744 \\
\hline
\end{tabular}

Source: Results of Author Processed Data From Smart PLS-SEM, (2021).

\section{Q-Square Predictive Relevance}

The result of the Q-Square Predictive Relevance value is 0.89 . Thus, it is said that this study has predictive relevance, because the value obtained is greater than 0 . For more details, see the results below:

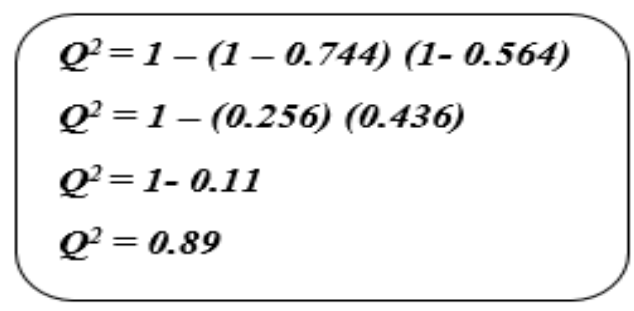

The value of Goodness of Fit (GoF) in this study is said to be good, because the results of the calculation are known to have a Q-Square Predictive Relevance value of 0.89 , so it can be interpreted that the amount of various data in this study has a developed structural model.

\section{Test Path Coefficients}

From the results, it can be seen that the T-statistic below 1.96 is an indicator of X2_4 or an indicator of the product quality variable (X2), namely conformity to specifications, because the T-statistic value is only 1.393 and X2_6 or an indicator of 


\section{International Journal of Current Science Research and Review}

ISSN: 2581-8341

Volume 05 Issue 02 February 2022

DOI: 10.47191/ijcsrr/V5-i2-33, Impact Factor: 5.825

the product quality variable (X2) namely aesthetics with a T-statistic value of only 1,622. From the results of testing with bootstrapping on the Path Coefficients test, it can be concluded that the T-statistic on the effect of promotion (X1) on purchasing decisions (Y) whose value is 4.748 , so $1^{\text {st }}$ Hypothesis can be accepted in this study. . That the T-statistic on the effect of product quality (X2) on purchasing decisions (Y) whose value is 1,435, so that the 2nd hypothesis cannot be accepted in this study.

That the T-statistic on the effect of promotion (X1) on consumer satisfaction (Z) whose value is 10,986, so the third hypothesis can be accepted in this study. That the T-statistic on the effect of product quality (X2) on consumer satisfaction (Z) whose value is 1,953 , so that the 4th hypothesis cannot be accepted in this study. That the T-statistic on the effect of consumer satisfaction $(\mathrm{Z})$ on purchasing decisions $(\mathrm{Y})$ whose value is 4,309 , so that the 5 th hypothesis can be accepted in this study. For more details, see the results below:

Table 12. Path Coefficients Test Results

\begin{tabular}{|l|l|l|l|l|l|}
\hline & $\boldsymbol{O S}$ & $\boldsymbol{S M}$ & SD & T-Statistic & P-Value \\
\hline $\mathbf{X 1 - > Y}$ & 0.482 & 0.474 & 0.102 & 4.748 & 0.000 \\
\hline $\mathbf{X 2 - > Y}$ & 0.073 & 0.076 & 0.051 & 1.435 & 0.152 \\
\hline $\mathbf{X 1 - > Z}$ & 0.708 & 0.706 & 0.064 & 10.986 & 0.000 \\
\hline $\mathbf{X 2 - > Z}$ & 0.134 & 0.150 & 0.069 & 1.953 & 0.051 \\
\hline $\mathbf{Z}->\mathbf{Y}$ & 0.436 & 0.441 & 0.101 & 4.309 & 0.000 \\
\hline
\end{tabular}

\section{Mediation Effect Test}

From the results of testing the mediating effect with bootstrapping, the results show that the T-statistic on the effect of promotion (X1) on purchasing decisions (Y) which is mediated by consumer satisfaction (Z) is 3,702, so the 6th hypothesis (Sixth) can be accepted in this study. That the T-statistic on the effect of product quality (X2) on purchasing decisions (Y) mediated by consumer satisfaction $(Z)$ is 1.751 , so the 7 th (seventh) hypothesis cannot be accepted in this study. For more details, see the results below:

Table 13. Specific Indirect Effects Results

\begin{tabular}{|l|l|l|l|l|l|}
\hline & OS & SM & SD & T-Statistic & P-Value \\
\hline $\mathbf{X 1 - > Z - > Y}$ & 0.309 & 0.313 & 0.083 & 3.702 & 0.000 \\
\hline $\mathbf{X 2 - > Z - > Y}$ & 0.058 & 0.066 & 0.033 & 1.751 & 0.081 \\
\hline
\end{tabular}

Source: Results of Author Processed Data From Smart PLS-SEM, (2021).

\section{DISCUSSION}

\section{The Effect of Promotion on Purchase Decisions}

The first result obtained from this research is that promotion has a significant and positive effect on purchasing decisions. This is understandable with the increasing number of promotions carried out by PT. Maybank Indonesia Finance, it will increase consumers to make purchasing decisions.

\section{The Effect of Product Quality on Purchase Decisions}

The second result in this study discusses the effect of product quality on purchasing decisions, from the results obtained it can be proven and accounted for that product quality does not have a significant and positive influence on purchasing decisions. These results are due to most of the respondents at PT. May-bank Indonesia Finance, is not too concerned with the aesthetics of a product, in this case four-wheeled vehicles, this is according to the author's observations because product financing is carried out by consumers at PT. Maybank Indonesia Finance, is a necessity to support consumer work, not just to satisfy consumer style

\section{The Effect of Promotion on Consumer Satisfaction}

The third result in this study proves that promotion has a significant effect on consumer satisfaction. It can be interpreted that the more intensive and the number of promotions carried out by PT. Maybank Indonesia Finance, will stimulate or stimulate 


\section{International Journal of Current Science Research and Review}

ISSN: 2581-8341

Volume 05 Issue 02 February 2022

DOI: 10.47191/ijcsrr/V5-i2-33, Impact Factor: 5.825

consumers to feel satisfied with the financing of the product taken, because what is being promoted is in accordance with consumer expectations.

\section{The Effect of Product Quality on Consumer Satisfaction}

The results of the influence of product quality on consumer satisfaction in this study prove that there is no significant effect between the two variables. These results, according to the author's point of view, are caused by conformance to specifications that cannot guarantee a product will fail or be defective in the product, not to mention that there are many counterfeit products, so this is impossible to fulfill.

\section{The Effect of Consumer Satisfaction on Purchase Decisions}

The fifth result of this study shows that consumer satisfaction on purchasing decisions has a significant and positive influence. It can be interpreted that the higher the satisfaction of consumers, the higher the purchasing decisions that consumers consider.

\section{The Effect of Promotion on Purchase Decisions Mediated by Consumer Satisfaction}

The sixth result of this study is related to the effect of promotion on purchasing decisions mediated by consumer satisfaction, the results prove that there is a positive and significant relationship. This means that the mediating parameter has a significant relationship.

\section{The Effect of Product Quality on Purchase Decisions Mediated by Consumer Satisfaction}

The seventh or last result in this study shows the effect of product quality on consumer decisions in mediating consumer satisfaction leading to no significant relationship on the mediating variable. This means that the mediation parameter is not significant in mediating the variables in this study.

\section{CONCLUSION}

From the various explanations that have been described, in the end several conclusions were obtained, including that promotion has a significant and positive influence on purchasing decisions at PT. Maybank Indonesia Finance, this is evidenced by the results of the T-statistic value obtained, which is 4,748. That product quality does not have a significant and positive effect on purchasing decisions at PT. Maybank Indonesia Finance, this is evidenced by the results of the T-statistic value obtained, which is 1,435. That promotion has a significant and positive influence on consumer satisfaction at PT. Maybank Indonesia Finance, this is evidenced by the results of the T-statistic value obtained of 10,986. That product quality does not have a significant and positive effect on consumer satisfaction, this is evidenced by the results of the T-statistic value obtained, which is 1,953 . That consumer satisfaction has a significant and positive influence on purchasing decisions, this is evidenced by the results of the T-statistic value obtained, which is 4,309 . That promotion has a significant and positive influence on purchasing decisions in mediating consumer satisfaction, this is evidenced by the results of the T-statistic value obtained, which is 3,702. That product quality does not have a significant and positive effect on purchasing decisions in mediating consumer satisfaction, this is evidenced by the results of the T-statistic value obtained, which is 1.751 .

\section{REFERENCES}

1. Armstrong and Kotler. 2013. Marketing Fundamentals. Volume I, Translated by Alexander Sindoro and Benjamin Molan. Jakarta: Prenhalindo.

2. Assauri, S. (2014). Marketing Management, Jakarta: Rajawali Press.

3. Dharmesta, Basu Swastha. 2011. Main Materials of Marketing Management. Second Edition, First Printing. Jakarta: Open University.

4. Hermawan, M. Ami Talib, et al. 2021. Assistance in Promotion of Pottery Tourism with Video Media in Pungkang Hamlet, Masbagik Timur Village, Journal of Community Service. Vol. 1, No. April 1st.

5. https://otomotif.kompas.com.

6. Kotler and Keller. 2012. Marketing Management. Volume I 12th Edition. Jakarta: Erlangga.

7. ------. 2016. Marketing Management, Edition 14 Volumes 1 and 2. Translation of Bob Sabran. Ja-karta: Erlangga. 


\section{International Journal of Current Science Research and Review}

ISSN: 2581-8341

Volume 05 Issue 02 February 2022

DOI: 10.47191/ijcsrr/V5-i2-33, Impact Factor: 5.825

IJCSRR@ 2022

www.ijcsrr.org

8. Kusumastuti, Fitri. 2011. The Influence of Price, Product Attributes and Promotion on Purchase Decisions for Sony Ericsson Cellular Phones (Case Study in Temanggung Regency). Essay. Semarang: UNDIP.

9. Nangin, MA., Barus, IRG., Wahyoedi Soegeng., 2020. The Effects of Perceived Ease of Use, Security, and Promotion on Trust and Its Implication on Fintech Adoption, Journal of Consumer Science, vol. 5 No. 2, pp. 124-138

10. Nasution, Muhammad Irfan, et al. 2017. The Effect of Product Quality, Promotion on Sales in Micro Business of Shoe Craftsmen in Medai Denai District. Journal of Social, Economics, and Humanities. Vol 7. No.1.

11. Priansa, D. J. 2017. Consumer Behavior in Contemporary Business Competition. Bandung: Alphabeta.

12. Maybank Indonesia Annual Report, (2020).

13. Maybank Finance Annual Report, (2020).

14. Lupiyoadi and Hamdani. 2011. Service Marketing Management. Jakarta: Salemba Empat.

15. Sangadji, E. M., and Sopiah. 2013. Consumer Behavior: Accompanied Practical Approach: Association of Research Journals. Yogyakarta: Publisher Andi.

16. Setyo, Purnomo Edwin. 2017. The Effect of Product Quality and Price on Consumer Satisfaction Best Auto-works. Journal of Management and Business Start-Ups, Vol. 1, No. 6.

17. Sudaryono. 2016. Marketing Management Theory And Implementation. Yogyakarta: ANDI.

18. Sugiyono, 2013. Educational Research Methods Quantitative, Qualitative, and R\&D Approaches. Bandung: Alphabeta.

19. --------, 2017. Quantitative, Qualitative and R\&D Research Methods. Bandung: Alphabeta.

20. Tjiptono, Fandy 2011. Service Man-agement Realizing Excellent Service. Edition 2. Yogyakarta: ANDI

21. Tjiptono, Fandy, 2012. Marketing Strategy, Edition. 3, Yogyakarta, ANDI.

22. --------. 2015. Marketing Strategy, Edition 4. Yogyakarta: ANDI.

23. ----------. 2014, Service Marketing, Principles, Application, and Research, Yogyakarta: ANDI.

24. Wijaya, Tony. 2018, Service Quality Management, Second Edition, Jakarta: Index

Cite this Article: Adwar Indra Laksana, Hery Winoto Tj., Soegeng Wahyoedi (2022). The Influence of Promotion and Product Quality on Purchase Decisions Mediated by Consumer Satisfaction at PT. Maybank Indonesia Finance. International Journal of Current Science Research and Review, 5(2), 568-581 